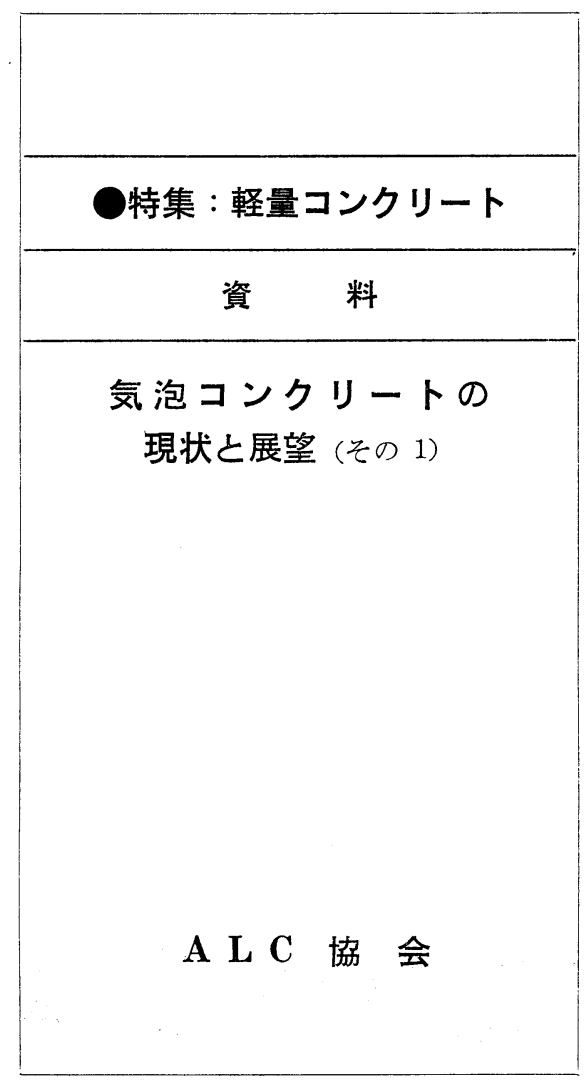

\section{ALC の概要}

\subsection{ALC とその歴史}

$\ulcorner A L C 」 は$, Autoclaved lightweight concrete の略 であり，「高温高圧蒸気養生された 軽量気泡コンクリー ト」のことである。

ALC 製品には，パネルとブロックがあるが，ALC パネルは, 工場生産のプレハブ構造パネルとして, 建築 物の屋根・床・外壁・間仕切などに用いられている。

気泡コンクリートの原始的な形のものは，ローマ時代 から使用されていたといわれているが，19 世紀ごろか ら種々の気泡コンクリートが開発された。

ALC は，このような長い歴史の蓄積によって生まれ たもので，いまから約 40 年ほど前，スウェーデンで初 めて工業生産化され，今日では世界の先進国において大 量に使われるようになっている。

わが国でも 1962 年ごろからその技術が導入され，現 在, シポレックス, ヘーベル, イトン, デュロックスの 4 品種が生産されている。なお, この間, 昭和 37 年に Vol. 13, No. 5, May 1975

\section{ALC の現況と今後の方向}

は日本建築学会に ALC 研究会 (会長・狩野春一博士) が組織され，わが国におけるALC の研究が広範に総合 的に行なわれた。昭和 42 年には建設省により「ALC 構造設計基準」が認定され, 昭和 47 年には ALC 製品 の JIS が制定された。また, 昭和 50 年 1 月には日本 建築学会より「JASS 21, ALC パネル工事」として, ALC 工事の標準仕様書が設定された。

複雑多岐にわたる現代建築の諸要求やプレハブ化, 超 高層化などの社会的発展を背景に, ALC の持つ特性が

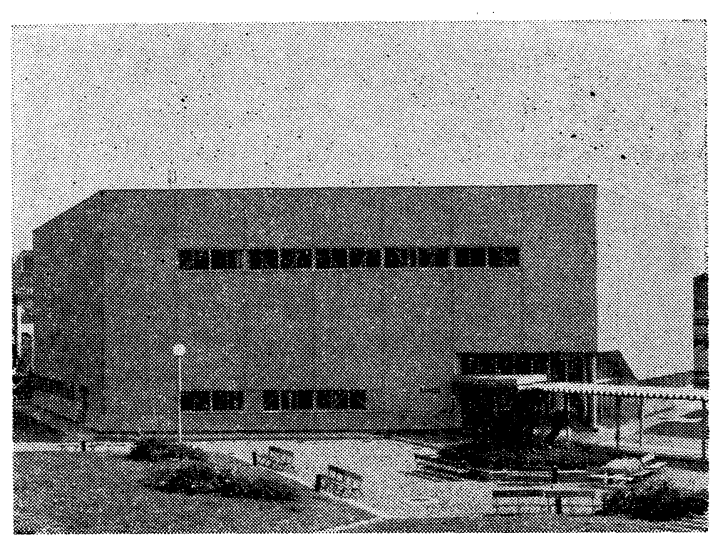

写真一1＼cjkstart建築物の外壁に ALC パネルを使用した例 


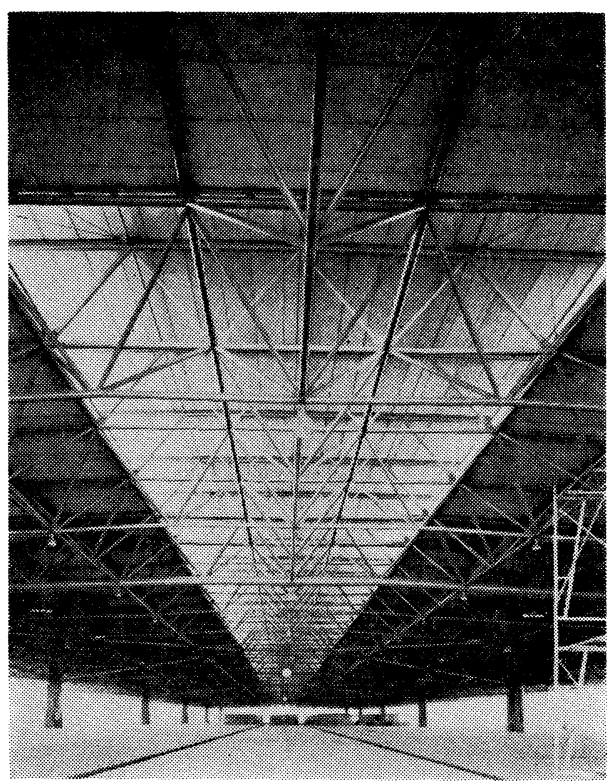

写真一2 屋根材に ALC パネルを使用した例

新しい時代に対応するものとして認識され，その需要は 急速に伸びている（写真-1, 写真-2）。

\section{2 製＼cjkstart法}

$\mathrm{ALC}$ はセメントや石灰などの石灰質原料 $(\mathrm{CaO})$ と， 硅砂, スラグ, フライアッシュなどの硅酸質原料 $\left(\mathrm{SiO}_{2}\right)$ を主とし，それに発泡剤としてアルミ粉末，気泡安定 剂，水などが加えられる (以下図一1参照)。

粉砕された原料は, ミキサーで混合され, あらかじめ 防錆処理された補強鉄筋がセットされている型わくの中 に流し込まれ発泡をはじめる。

こうしてできた多孔質のケーキを, カッターで版状に 切断したのち, 10 数時間オートクレーブ（高温高圧蒸 気釜) で養生して完全な製品ができ上がる。

このように，ALC は，硅砂と石灰が直接結合して， まったく新しい物質を創り出すので，砂や砂利を単なる 骨材として使用しているコンクリートとは大いに異なる 性能が得られる。

\section{3 製品}

ALC 製品には, 補強鉄筋を組込みパネル状に成形し た ALC パネルと, ブロック状に成形した無筋の ALC ブロックとがある。わが国では, 主として ALC パネル が使用され，ALC ブロックは殆ど使用されていない。 ALC パネル は工場生産のプレキャストパネルである が, 使用部位によりパネルの仕様が異なり, 屋根版・床

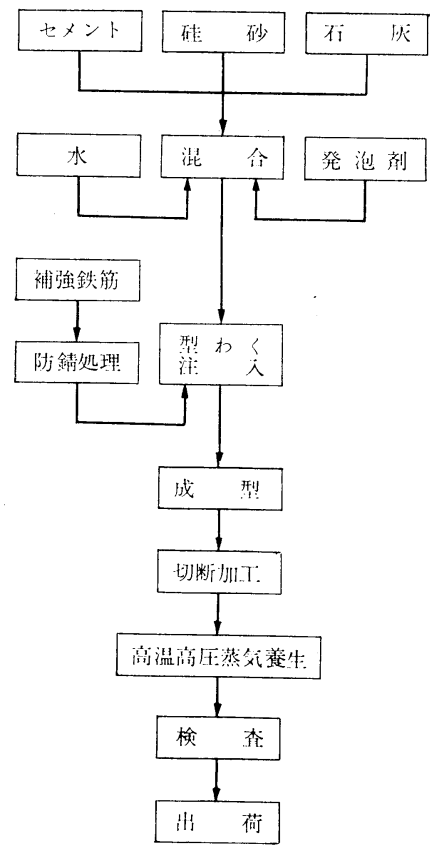

図一1 ALC のフローシート

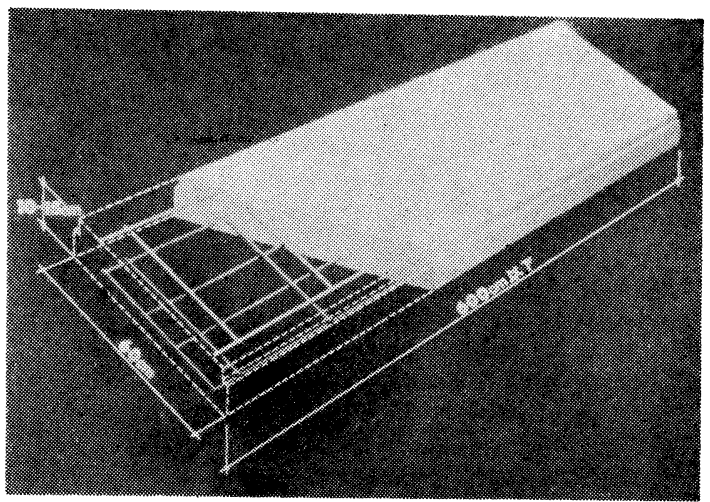

図一2 ALC パネル

版・外壁版・間仕切版等に分類される。

\section{4 特 長}

（1）軽 量 性

ALC の比重は絶乾でわずか 0.5 (ALC 構造設計基 準では鉄筋やモルタルを含み，比重 $=0.65$ と規定）に 寸ぎない。これは普通コンクリートの約 $1 / 4$ という軽さ で，基礎や躯体工事費を低減し，施工の合理化や工期の 短縮をはかることができ，また建築の高層化を容易にす るとともにプレハブ化を促進する。

（2）強度

ALC は, コンクリートの $1 / 4$ といら軽さにもかかわ 
らず，補強鉄筋の働きにより構造部材として十分安心し て使用できる。

また，補強鉄筋はすべて防錆処理がほどこしてあるの で，発錆腐食による強度低下のおそれはない。

\section{（3）耐 久 性}

ALC は無機質の断熱材であるため耐火性にすぐれて おり，災害時には有毒ガスなどの放出もない。また法定 不然材であるとともに, 耐火に関しては建設大臣からす べての部位について次のように耐火構造部材としての锠 定を受けている。

屋根版 $=30$ 分 壁 ・間仕切版 $=2$ 時間

床 版 $=1 \sim 2$ 時間 柱耐火被覆 $=2 \sim 3$ 時間

\section{（4）断 熱 性}

ALC は無数の細かい独立気泡を含んだ多孔質製品で あり，したがって高い断熱性を持っている。

熱伝導率は絶乾 $=0.08$, 気乾 $=0.13 \mathrm{kcal} / \mathrm{mh}^{\circ} \mathrm{C}$ で, 普通コンクリートの約 $1 / 10$ に相当するので, 結露防止 のほか居住性を高め冷暖房費の低減にも役立つ。

\section{（5）遮 音 性}

一般に軽量の材料は音を伝えやすいものとされている が, ALC は軽量にもかかわらず, 他の軽量部材と比較 して遮音性能がよく, 長屋または共同住宅の界壁の遮音 構造として建設大臣の指定を受けており, 住宅をはじめ 高度な居住性を必要とする病院, 図書館, ホテル, 研究
所，事務室などに使用されている。

\section{（6）プレハブ性}

ALC はプレハブ部材として安定した品質と高い寸法 精度を持っている。また加工性もよいところから，作業 の能率を向上させ，より一層の工期短縮が可能である。

\section{5 性 能}

ALC は高度の品質管理のもとで生産される工場量産 品であるから, その品質は常に安定し, 製品による性能 のぼらつきも少ない。表一1に ALC の物理的諸性質を 示す。

\section{2. 生産の現況}

\section{1 企業 形態}

ALC メーカー数は現在 表一2 の 5 社 (11 工場) であ り，すべてが大企業ないしは大企業関連会社であるこし が特色といえる。

工場は東京, 大阪, 名古屋地区周辺に集まっている。 なお, シポレックス 2 社の製品はシポレックス（株） が，イトンの製品は日本セメント（株）イトン事業本部 がそれぞれ販売を行なっている。

表一1 A L C の 物 理 的 諸 性 質

\begin{tabular}{|c|c|c|c|c|}
\hline & 目 & 数 & 測 定 条 件 & 備 \\
\hline 量 & $\begin{array}{l}\text { 絶 乾 比 重 } \\
\text { 気 乾 比 重 } \\
\text { 構造計算用重量 }\end{array}$ & $\begin{array}{l}0.5 \\
0.5 \sim 0.6 \\
650 \mathrm{~kg} / \mathrm{m}^{3}\end{array}$ & $\begin{array}{l}\text { 絶 乾 状 態 } \\
\text { 気 乾 状 態 } \\
\text { ALC 構造設計基準 }\end{array}$ & $\left\{\begin{array}{l}\text { 1. 補強鉄筋, 目地モルタル, 星付金物等を含む } \\
\text { 2. 普通コシクリート重量の } 1 / 4\end{array}\right.$ \\
\hline 強 & $\begin{array}{l}\text { 圧 縮 強 } \\
\text { 度 } \\
\text { 曲 強 度 } \\
\text { せん断強度 } \\
\text { 引張強度 } \\
\text { ヤング係 数 }\end{array}$ & $\begin{array}{c}40 \mathrm{~kg} / \mathrm{cm}^{2} \\
10 " \prime \\
5 " \\
5 " \\
1.7 \sim 2.2 \times 10^{4} \mathrm{~kg} / \mathrm{cm}^{2}\end{array}$ & $\begin{array}{c}\text { 気 乾 状 態 } \\
" \prime \\
" \\
" \\
"\end{array}$ & \\
\hline $\begin{array}{l}\text { 断 } \\
\text { 熱 }\end{array}$ & $\begin{array}{l}\text { 熱 伝 導 率 } \\
\text { 熱膨張 係 数 }\end{array}$ & $\begin{array}{c}0.13 \mathrm{kcal} / \mathrm{mh}^{\circ} \mathrm{C} \\
7 \times 10^{-6}\end{array}$ & $\begin{array}{c}\text { 気 乾 状 態 } \\
" \prime\end{array}$ & 普通コンクリートの $1 / 10$ \\
\hline 音 & $\begin{array}{l}\text { 吸音 率 } \\
\text { 透過損 失 }\end{array}$ & $40 \mathrm{~dB}$ & $\begin{array}{l}1000 \mathrm{~Hz} \text { のとき } \\
1000 \mathrm{~Hz} 10 \mathrm{~cm} \text { 厚 } \\
\text { のとき }\end{array}$ & 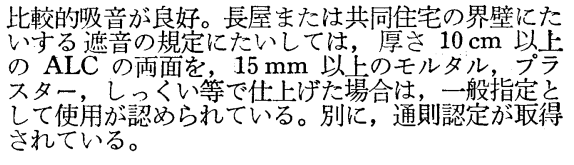 \\
\hline 水 & $\begin{array}{l}\text { 部分吸水率 } \\
\text { 吸湿率 } \\
\text { 乾燥収縮率 }\end{array}$ & $\begin{array}{c}20 \sim 23 \% \text { vol } \\
2.5 \% \text { vol } \\
0.025 \sim 0.05 \%\end{array}$ & $\begin{array}{l}10 \mathrm{~cm} \text { 章方体下部 } 1 \mathrm{~cm} \\
\text { を水中浸漬 } 100 \text { 日間 } \\
20^{\circ} \mathrm{C}, \mathrm{RH} 65 \% \text { の状態 } \\
\text { で放置 } \\
\text { 飽和状態から気乾状態ま } \\
\text { での乾燥収縮率 }\end{array}$ & $\begin{array}{l}\text { 防水コンクリートブロック JIS 防水試験に 仕上げ } \\
\text { なしで合格 }\end{array}$ \\
\hline
\end{tabular}


表一2 ALC 品種名およびメーカー

\begin{tabular}{|c|c|c|}
\hline 品種 名 & 製 造会社名 & 備 \\
\hline シポレックス & シポレックス製暹（株） & $\begin{array}{c}\text { 住友金属鉱山 (株) } \\
\text { グループ会社 }\end{array}$ \\
\hline シポレックス & 日本シポレックス業 & $\begin{aligned} & \text { 早硝子 } \text { (株) } \\
& \text { グループ会社 }\end{aligned}$ \\
\hline イトン & 日本イトン工業（株） & $\begin{array}{l}\text { 販売·施工： } \\
\text { 日本セメント(株) } \\
\text { イトン事業本部 }\end{array}$ \\
\hline ヘーベル & 旭化成工柴（株） & \\
\hline デュロックス & 小野田エー・エル・ & $\begin{array}{r}\text { 小野田セメント(株) } \\
\text { グループ会社 }\end{array}$ \\
\hline
\end{tabular}

\section{2 流通機構}

各社によって若干異なるが，おおむる称次の形態がとら れている。一般に製品は工場渡しで, 請負業者に直接販 壳されるものと, 代理店を通じ請負業者に販売されるも のと 2 つの形態がとられており, 問屋あるいは小売店な どの中間的流通機構はない。また施工についても, 責任 施工を行なっているものと代理店が行なっているものと の 2 つ形態がとられている。

\section{3 需 要 動 向}

建築物の高層化，特釷鉄骨造の急增により，こ礼に使 用される建材は軽量化が要請され, また一方では建設労 務者の不足等に対処する必要から, 建築のプレハブ化が 促進されるわけであるが, この点 ALC は両者の条件を 具備しているものであり, いわば社会的要請に応え得る 製品であるといえる。加えて高度の居住性が加味され, また, 生産面, 使用面共, 省エネルギー建材であるとこ ろから, 需給は図一-3のとおり年ごとに好調に推移して いる。今後も建築物の不燃化, 高層化という社会的傾向 がっぶくかぎり, ALC もその特性を発揮し, 新しい時 代の新しい「素材」としてさらに飛躍するものと思われ る。

図一4 に製品の部位別構成比の推移を示す。また，図 -5 に地域別需要量を示す。

\section{4 規 格}

ALC 製品には, 屋根版, 床版, 外壁版, 間仕切版等 の種類があるが，それぞれに規格品，標準品，特注品の 別がある。特注品は規格品等に比較して割高となり，ま た納期も長くかかるから，計画当初より規格品を検討し て，それに合った設計をすすめるのがよい。

しかしながら，実際の規格品の使用率は，未だかなり 低い。図一6は，ある社の，ある時期に打けるALC パ

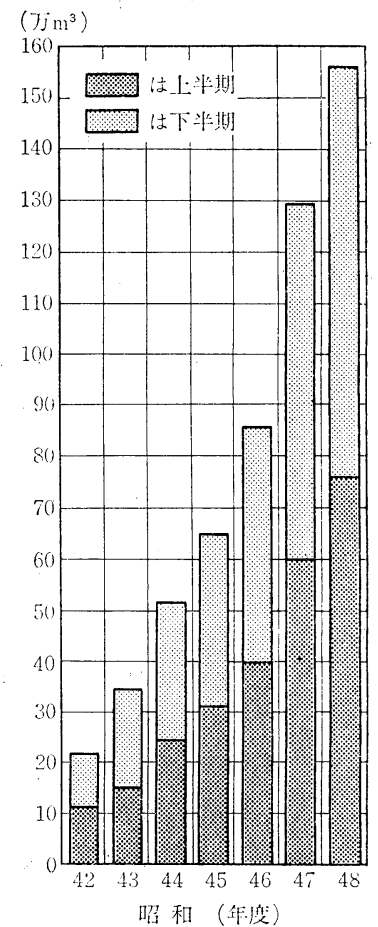

図一3建筑物の不燃化，軽量化，省力化などの ニーズが高まるにつれて，ALC の生産 は急激にふえている

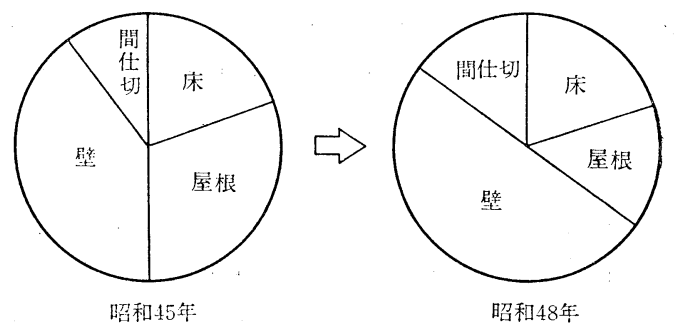

图-4 ALC の部位別構成比

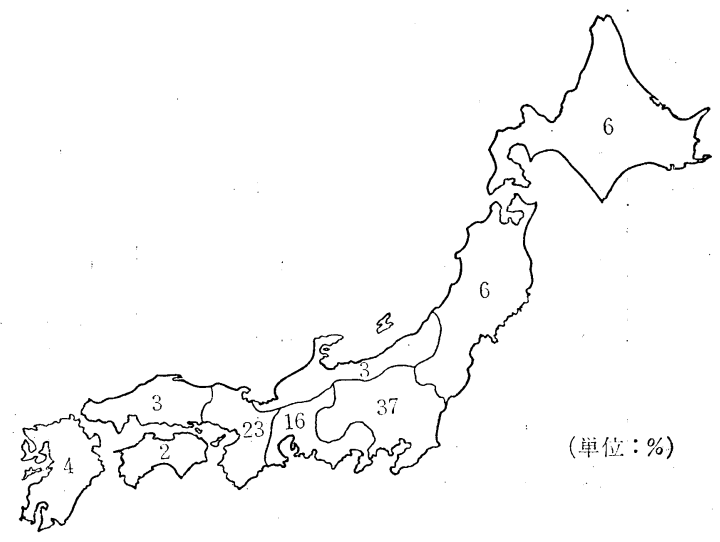

図一5 ALC の地域別需要量（昭和 48 年推定） 
ネルの部位別生産比率を示す。また，参考として図一7 亿，厚さ別生産比率を示す。

ALC は，西ヨーロッパ諸国で開発され，それぞれわ が国に技術導入されて生産されているわけであるが, ヨーロッパ諸国で，すでに $\mathrm{L}_{3}$ (注) 材のオープン部品と して使用されているものが，そのままわが国汇導入され た。しかしながら，わが国では設計のオープン性も市場

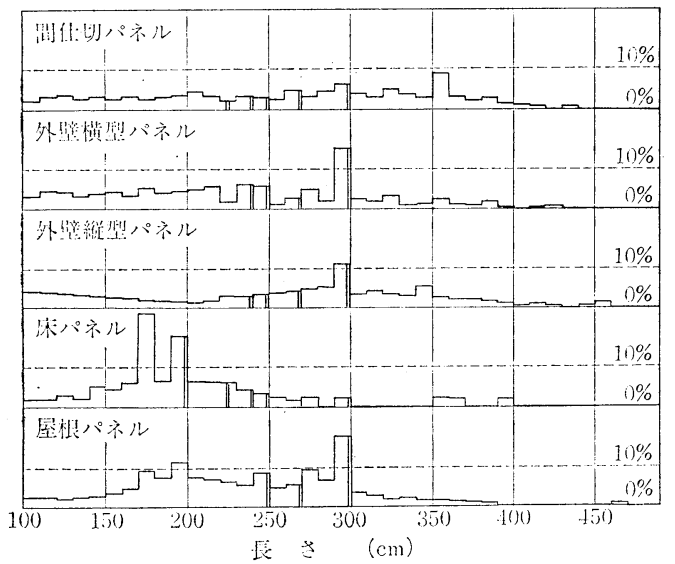

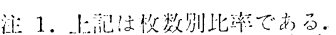

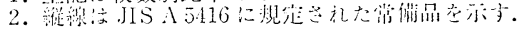

図一6 ALC パネルの部位別長さ別生産比率
のオープン性も確立されておらず，したがって，ALC の開発は任意に計画されたものに，ALC パネルをはめ 込む作業と考えられていることが多い。

ALC は, 構造耐力の面でも, 切断加工をしない $\mathrm{L}_{3}$ 材として使用しなければならないので，ALCメーカー としては，原則として見込生産を前提とする規格品と， かなりの種類の標準品——受注生産品——用意して需 要に応じている。ALC は体積が大きく, 見込生産品穵 あらかじめ備蓄することも，物理的にかなり制限され る。一方, ALC の生産は, 一定の大型モールドに鋳込 みそれを切断することで行なわれるために, 種々のパネ

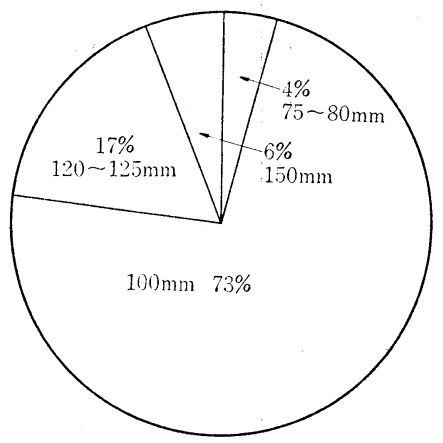

图一7ＡLC パネルの厚さ別生産比率

表一3 A L C 規 格品 パネル は JIS A 5416 に規定された常備品)

\begin{tabular}{|c|c|c|c|c|c|c|c|c|c|c|c|c|c|}
\hline \multirow{2}{*}{ 部 } & \multirow{2}{*}{ 位 } & \multirow{2}{*}{$\begin{array}{c}\text { 荷 重 } \\
\left(\mathrm{kg} / \mathrm{m}^{2}\right)\end{array}$} & \multirow{2}{*}{$\begin{array}{l}\text { 厚 さ } \\
(\mathrm{mm})\end{array}$} & \multicolumn{5}{|c|}{ 長 } & \multicolumn{5}{|c|}{$(\mathrm{mm})$} \\
\hline & & & & 1800 & 2000 & 2250 & 2400 & 2500 & 2700 & 3000 & 3200 & 3500 & 3600 \\
\hline \multicolumn{2}{|c|}{ 屋根パネル } & 100 & $\begin{array}{r}75 \\
100 \\
125\end{array}$ & $\begin{array}{l}0 \\
0\end{array}$ & $\begin{array}{l}0 \\
0\end{array}$ & $\bigcirc$ & ○ & 0 & ○ & 0 & & 0 & \\
\hline \multirow{4}{*}{ 床パネル } & \multirow{2}{*}{$\begin{array}{l}1 \text { 時間 } \\
\text { 酎 火 }\end{array}$} & 240 & $\begin{array}{l}100 \\
125 \\
150\end{array}$ & $\bigcirc$ & 0 & $\begin{array}{l}0 \\
0 \\
0\end{array}$ & $\begin{array}{l}0 \\
0 \\
0\end{array}$ & $\begin{array}{l}0 \\
0\end{array}$ & $\begin{array}{l}0 \\
0\end{array}$ & $\begin{array}{l}0 \\
0\end{array}$ & & & \\
\hline & & 360 & $\begin{array}{l}100 \\
125 \\
150\end{array}$ & 0 & $\begin{array}{l}0 \\
0\end{array}$ & $\begin{array}{l}0 \\
0\end{array}$ & $\begin{array}{l}0 \\
0\end{array}$ & $\begin{array}{l}0 \\
0\end{array}$ & ? & 0 & & & \\
\hline & \multirow{2}{*}{$\begin{array}{l}2 \text { 時間 } \\
\text { 酎 火 }\end{array}$} & 240 & $\begin{array}{l}125 \\
150\end{array}$ & $\bigcirc$ & $\bigcirc$ & $\begin{array}{l}0 \\
0\end{array}$ & O & 0 & - & 0 & & & \\
\hline & & 360 & $\begin{array}{l}125 \\
150\end{array}$ & 0 & $\bigcirc$ & $\bigcirc$ & $\bigcirc$ & - & - & ○ & & & \\
\hline \multirow{2}{*}{ 壁 パ } & \multirow{2}{*}{ ネ ル } & 120 & $\begin{array}{l}100 \\
125\end{array}$ & & & & ○ & ○ & 0 & 0 & $\begin{array}{l}0 \\
0\end{array}$ & $\begin{array}{l}0 \\
0\end{array}$ & O \\
\hline & & 200 & $\begin{array}{l}100 \\
125\end{array}$ & & & & 0 & 0 & 0 & 0 & O & 0 & 0 \\
\hline \multicolumn{2}{|c|}{ 間仕切パネル } & - & 100 & & & 0 & - & ○ & - & 0 & O & O & $\bigcirc$ \\
\hline
\end{tabular}

（注）「住宅の部品化に関する研究報告」(昭和 43 年 3 月 日本建築センター)

部品の分類 : 部品を，あらかじめ工場就いて製作された形での大きさの内，現場において調整埕ずに組立て得る方向の数 によって, $\mathrm{L}_{0}$ 材, $\mathrm{L}_{1}$ 材, $\mathrm{L}_{2}$ 材, $\mathrm{L}_{3}$ 材に分類する。 $\mathrm{L}_{3}$ 材は現場調整を要せず，そのまま使用できることを意味する。 
ルをいかに組合せて鋳込むかが重要な作業となる。この ため,メーカー各社はコンピューターを使って, 受注さ れた多種類のパネルの多数の案件を, 一度分解し, 組合

\section{表-4 ALC 標準品パネル}

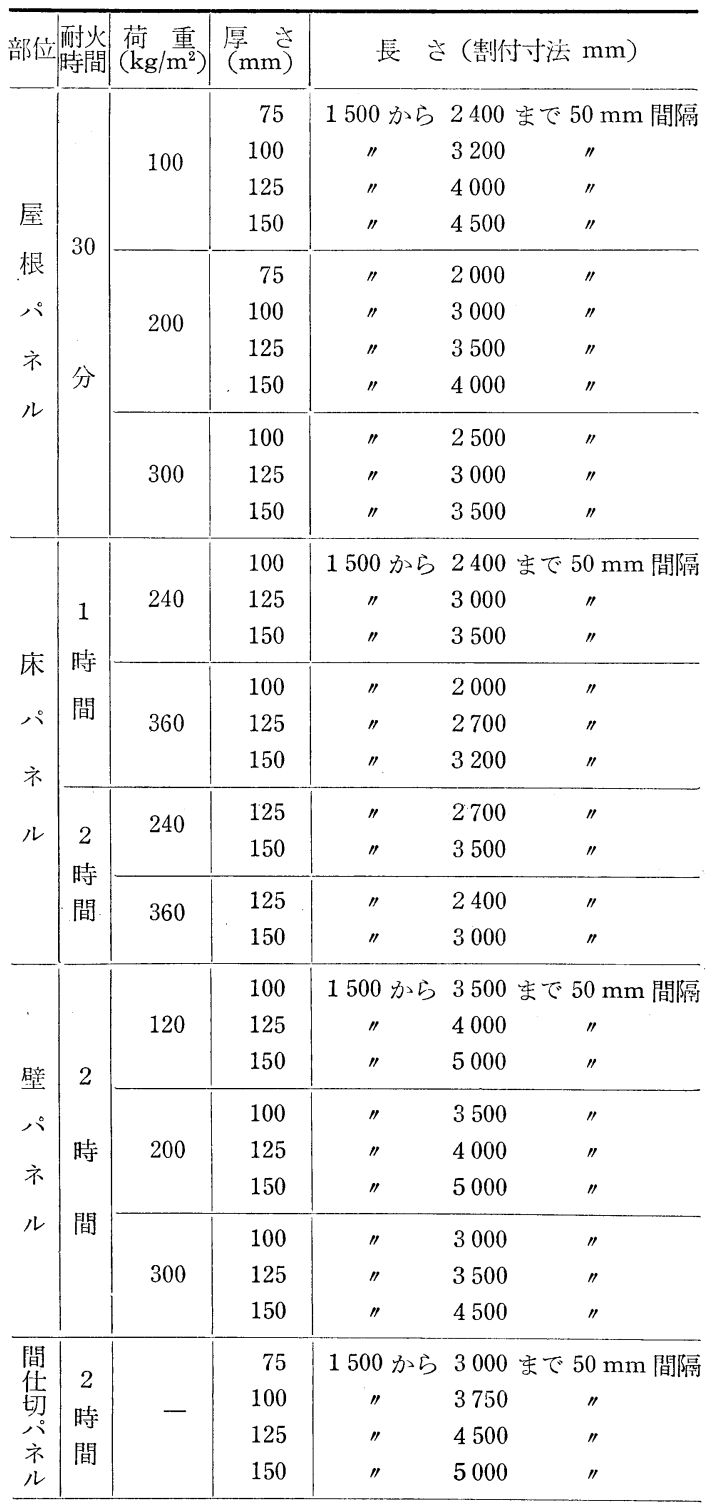

パネル幅 $=600 \mathrm{~mm}$
せて生産し，案件別に分類し入庫し輸送する作業を行 なっている。これが近年では, 物流だけでなく商流まで コンピューター管理を行なっている社むある。このよう にして, 各種類の受注されたパネルを能率よく生産して いるわけであるが，規格化が生産，建設共に合理化に大 きくつながることは, 当然であり, ALC の JIS も, 規 格化とこれによる建筑生産の効率化に大きな期待がかけ られて制定された。ALCメーカーも，規格化の推進に 今後も努力を続けていく考えである。

\section{5 価格}

ALC は優れた建材であるが，価格が高いといわれて きた。しかし最近 ALC の持つ軽量性, 施工性, 工期の 短縮などが益々重視されるにつれて, 次の有利性が増大 している。この点を調査するために, ALC 協会で「建 築コスト調查特別委員会」が設けられ，このほど「建築 コスト調查報告書一 $\mathrm{ALC}$ 造と R C 造の経済比較」が 作られた。この調查では，できるだけ客観的な結果を得 ることを意図し，各 ALCメーカーの技術者と積算事務 所, および建築編集事務所(注) が参加して行なわれた。

経済的メリットの比較に関しては『公団住宅程度の建 物』を, また，経済数值の基準化に関しては『設計事務 所やゼネコン設計部の設計による実例』を中心に，でき るだけ標準的な建物の中から，無作為に標本を抽出し， 数多くの物件の平均化された数值を求める方法を採用し た。

さらに，鉄骨造の水平部位を構成する各種工法と ALC 造とを比較検討した。この報告の詳細は，ALC 協会の報告書にゆずるが，結論の一部を紹介する。

公団集合住宅程度の建物で, 壁式R C造と, ALC を 全面的に使用した鉄骨造とを比較する。

\section{（1） $\mathbf{m}^{2}$ 当りの総工費と経年変化}

$\mathrm{ALC}$ 造は $\mathrm{RC}$ 造より $\mathrm{m}^{2}$ 当りの建築コストが安く, しかも物価（主として人件費）騰貴の影響から，今後， $\mathrm{ALC}$ 造と R C 造の建築コストの差は, より大きくなる 傾向がある。

表一5 $\mathbf{m}^{2}$ 当りの総エ費

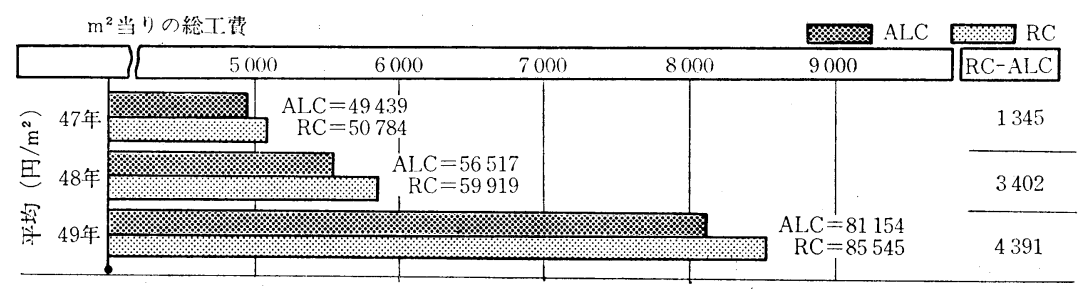

（注）主として建築, 建材関係, 資料, カタログ, 単行本, 雑誌等の企画, 編集, デザイン等を業とする事務所。 


\section{（2）建築規模と建築コスト}

ALC 造は，建築規模がコストにおよぼす影響は小さ く, 建築規模の大小に関係なく, その経済的メリットを 生かすプレハブ工法であり，小さな規模の建築でも，経 済特性を十分発揮できる。

\section{（3） $\mathbf{m}^{2}$ 当りの各工事費の構成}

すべての工事において ALC 造のコストは， R C 造よ りも低い。特に，ALC 造の高いプレハブ性による工期 の短縮は，諸経費において， R C造より，約 15〜20\% の節約を可能にする。

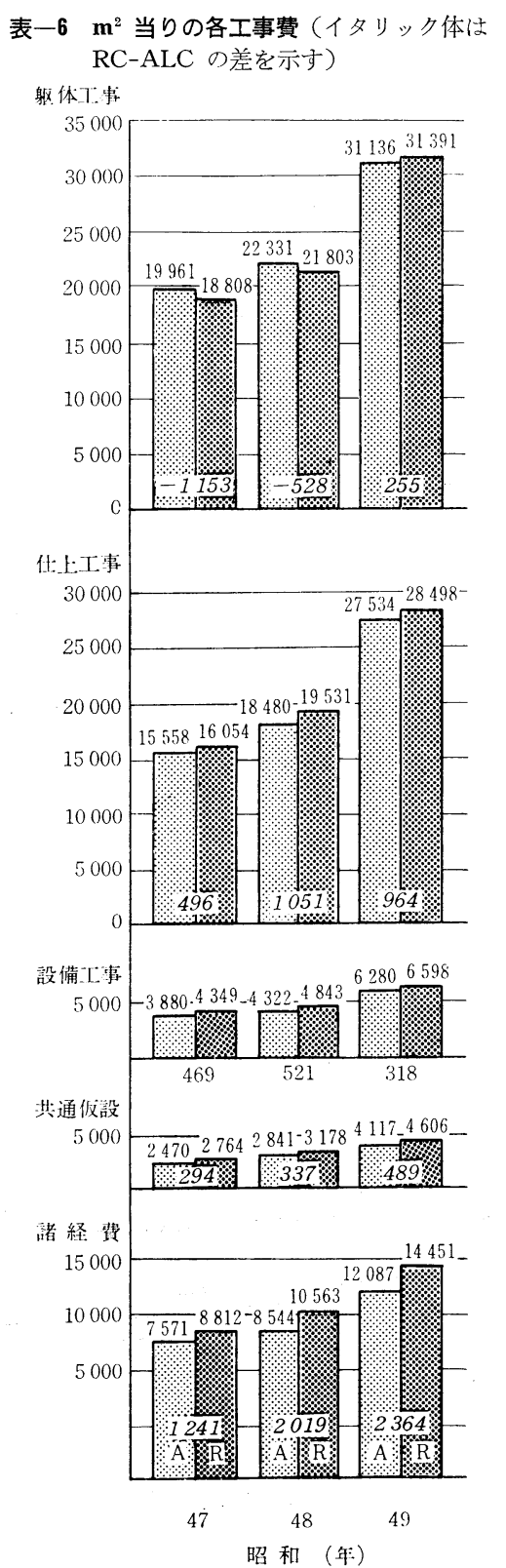

\section{(4) 躯体工事と仕上工事}

各年の, 総工事費に対する躯体工事費と仕上工事費の 割合をみると，ALC 造・R C 造ともいずれの年も，躯 体工事費の方が仕上工事費よりも大きいことが明らかで ある。また，年とともに躯体工事費の割合は減少し，逆 に仕上工事費の占める割合が増加している傾向がみられ る。特に, ALC 造にその傾向が強くみられるが, ALC 造は R C 造に比較して躯体工事費の占める割合が大きい 工法なので，その割合が減少していくこの傾向から， ALC 造は, 今後, 経済的な面で, より有利な工法であ るといら見方ができる。

なお，この場合，標本として住宅公団程度の公共住宅 を取り上げているので，一般的には，これよりグレード の高い仕上げや設備を行なっていることを考えると，こ の比率はさらに広がるものと思われる。

なお, 参考として, 表一7 に ALC の建物種別使用量 を示す。

\section{表-7 ALC の建物種別使用量}

\begin{tabular}{|c|c|}
\hline & $\begin{array}{c}\mathrm{ALC} \text { 使用量 } \\
\left(\mathrm{m}^{3} / \mathrm{m}^{2}\right)\end{array}$ \\
\hline $\begin{array}{l}\text { 中規模 建 築物 } \\
\text { 鉄骨 } \mathrm{ALC} \text { 造, } 2 \text { } 2 \text { 階建, 延面積 } 200 \sim \\
1600 \mathrm{~m}^{2} \text {, 事務所ビル等 } 13 \text { 例の平均 } \\
\text { ALC 使用部位 : 屋根, 床, 外壁, 間仕切壁 }\end{array}$ & 0.24 \\
\hline $\begin{array}{l}\text { 中層集合住宅 } \\
\text { 鉄骨 ALC 造 } \\
\text { ALC 使用部位 : 屋根, 床, 外壁, 間仕切壁 }\end{array}$ & $0.25 \sim 0.26$ \\
\hline $\begin{array}{l}\text { 独 立 住 宅 } \\
\text { ALC 酎力壁造 } \\
\text { ALC 使用部位: 屋根, 床, 外壁, 間仕切壁 }\end{array}$ & $0.35 \sim 0.40$ \\
\hline
\end{tabular}

\section{ALC パネルの設計および施工方法}

ALC を使用する場合の注意事項などを紹介する。

（i ）「正しい打合せ」がすべての基礎である。設計 が具体化した段階で，採用目的を満足させるよう に，使用上の問題点等を検討する。

(ii） ALC パネルを使用するときは，できるだけ少 ない種類の規格品で間に合うように計画すること が大切である。

（iii）鉄骨など構造体の精度は ALC 工事の仕上りを 決定する重要な要素である。鉄骨面の変位は予想 外に大きいことがあるので支持材の断面決定に際 しては，曲げ応力による算定だけでなく，必ず剛 性に対する検討を行なら必要がある。

（iv）取付工法は，実験等の裏付けもあり，実績もあ 
(1) 屋根・床パネル

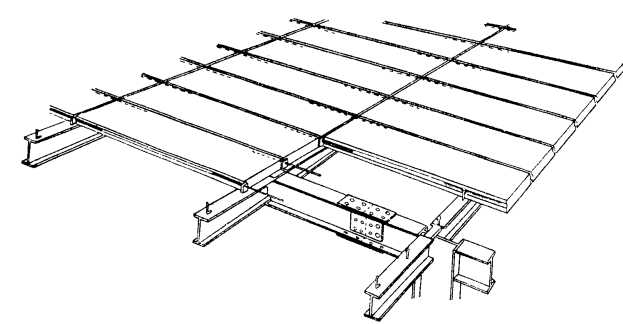

一般短辺接合部

目地流し筋 10 并10 取付けピース プレー電涴

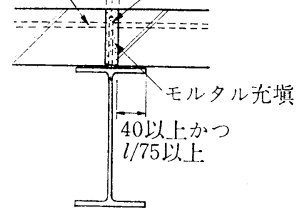

周 辺 部

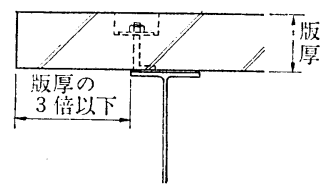

(2) 外壁堅壁パネル
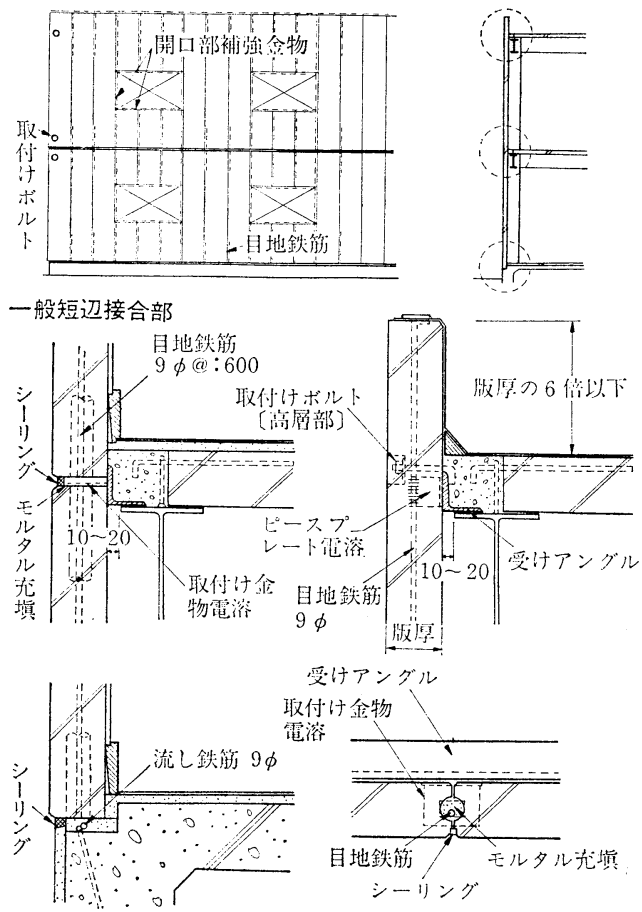

图一8 鉄骨構造における ALC パネルの取付方法（その 1)

(3) 外壁横壁パネル
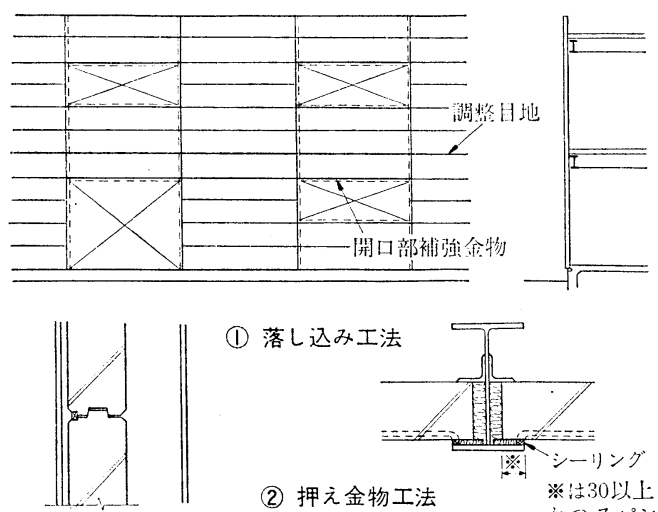

(1) 落し込み工法

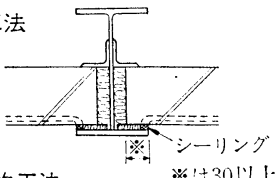

(2) 押元金物工法济30以上
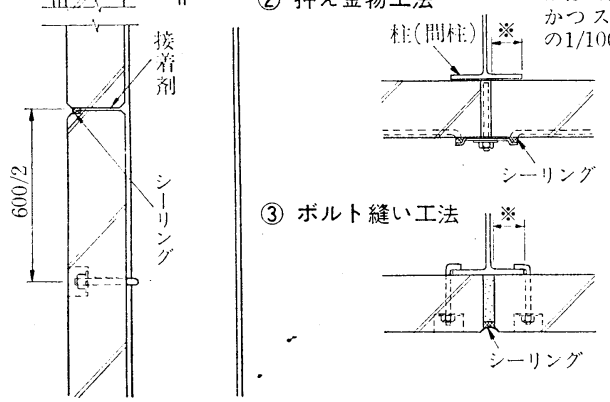

(3) ボルト縫い工法

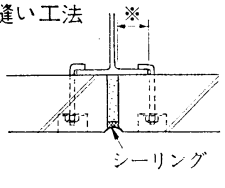

(4) 間仕切りパネル

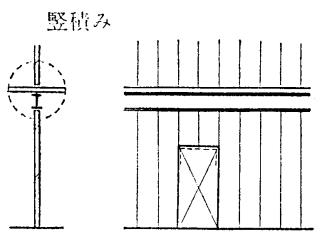

横枯み

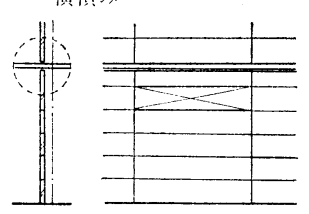

岵式上江地

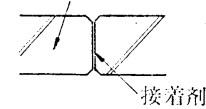

(1) ボルト縫いエ法

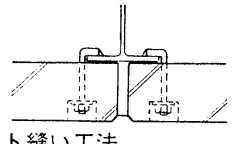

湿式地目地モルタル无境
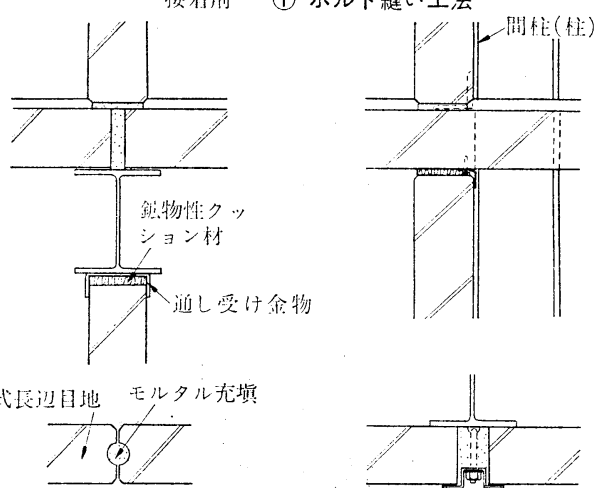

(2) 押元金物工法

図一9 鉄骨構造における ALC パネルの取付方法（その 2 ) 
る標準工法を採用すべきである。こうすれば職人 が馿れている上に専用の副資材なども用意されて いるので安全かつ経済的に工事を進めることがで きる。

（v） パネルの切断・欠き込みは，構造耐力上も，施 工能率上も大きな支障となるので, 計画の段階で 避けるように努める。

（vi） パネルの支持面は平坦にする必要があり，はり のジョイント部などのガセットプレート・リベッ 卜頭等には特に注意を要する。

（vii）パネルへの過大な集中荷重は避けるよう定めら
れており, 広告塔, 水槽などの重量物は, 必ず構 造躯体に直接支持するようにする必要がある。

(viii) ALC の外壁は, 両端支持のパネルによって褠 成されているので, 壁面に空などの開口部を設け る場合は開口部補強を行なら必要がある。

（ix）取付けのむずかしい，開口部の垂れ壁や袖壁， パラペットの持出しなどの特殊部分，および，水 漏れの恐れのある軒廻りやドレン迴りなどの納り には計画・施工共特に留意する必要がある。

（x） ALC パネルは，原則として仕上げが必要であ る。特に床・歩行用屋根には耐衝撃性, 耐摩耗性
(5) ALC 耐力壁造

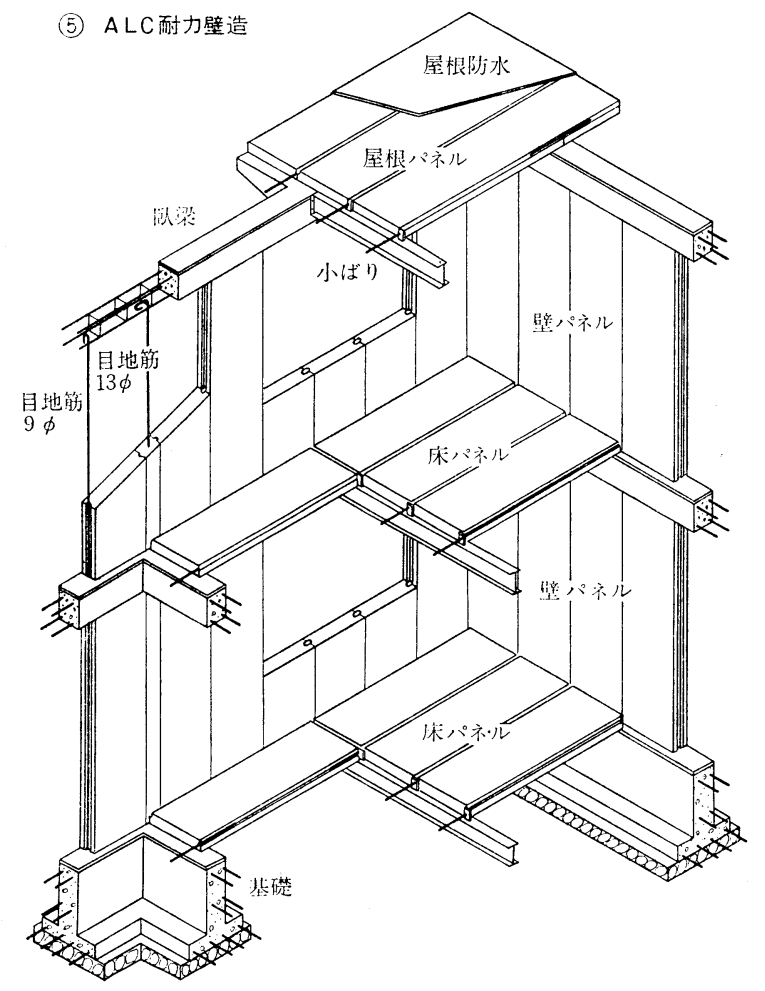

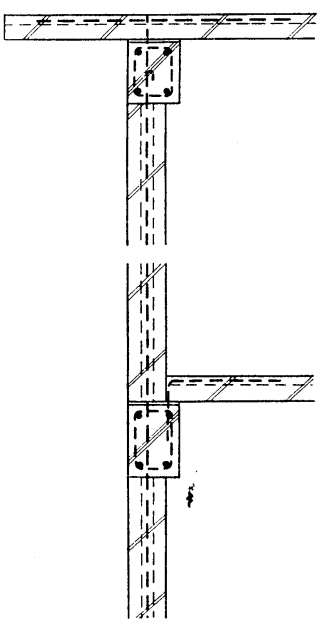

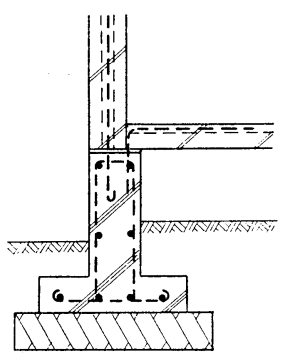

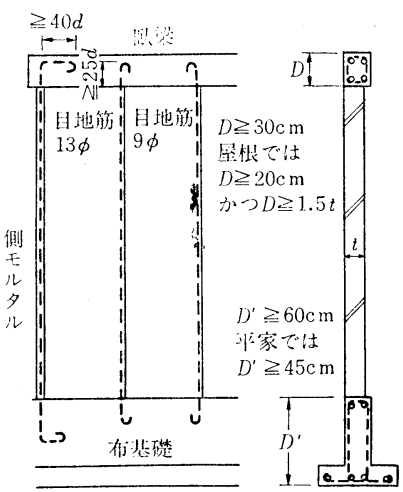

臥梁㧍よび布基礎との定着
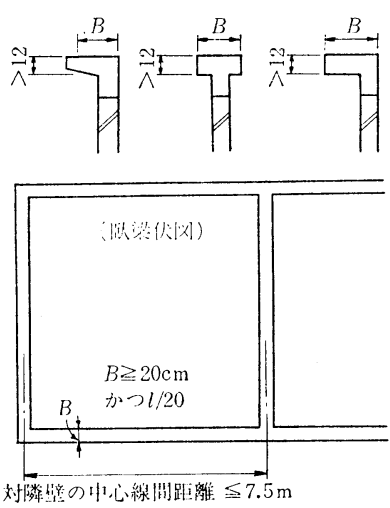

臥梁の有効幅 B

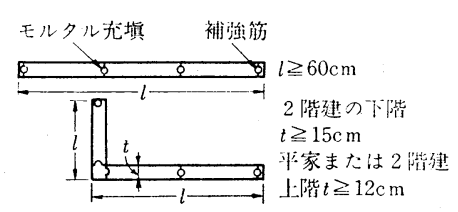

ALC 耐力壁の長さおよび厚さ

図一10 ALC 耐力壁構造における ALC パネルの取付方法 
のある仕上げ，また屋根には耐久性の高い防水仕 上げをする。また，外壁面には防水性のある合成 樹脂系塗料の吹付仕上げが必要である。

（xi） ALC パネルは，かなり大型のプレキャストパ ネルなので，この利点を生かすため，搬入，仮 置，荷揚げ，取込み，取付け等について合理的に 計画し，施工しなければならない。また ALC工 事の着工前に施工寸る工事と，後に施工する工事 を良く検討し，関連工事を含めて段取りよく計画 する。

図一8，図一9，図一10により，ALC パネルの基本的 な取付方法を示した。

\section{ALC の今後の方向}

\section{1 用途上の拡販の方向}

わが国の経済は，今までのような急成長は望めず，安 定的な成長にとどまるといわれている。しかしながら， ALC は相変わらず続く建築生産工業化の要請や, 木材 資源代替, 省エネルギー建材一の期待により, 今後共か なりの拡大が見込まれている。その中で, 特に増加する 可能性があるものに, 鉄骨造ビルの床需要と, 住宅関連 需要がある。

床需要に付いては, 図一4 の部位別構成比の推移を見 ても, ALC 全体の延びと同様に, 順調に増加してい る。しかし, 高層建築物の場合, 床の面積は壁面積の数 倍であるのが通常であり, この潜在需要はかなりのもの があろら。これに対し，ALC 業界としては, 実施例の 紹介を伴った P R の撤底を計ると同時に，仕上工事等を 含めた工法の再検討に努めている状況である。

また, 住宅関連需要は, 今後共膨大なものがあるが, 現在のところ, わが国ではたかだか ALC 全体の使用量 の $10 \%$ 前後しか使用されていないといわれている。こ れに対し, 例えばスウェーデンでは約 $50 \%$ が住宅関連 需要に使用され, その内の約半分, $25 \%$ 程度が, 低層 住宅に使用されている。わが国でも, 住宅需要は, 経済 全体の低成長にもかかわらず増々大きくなるであるう し，木材資源を代替する耐火断熱，プレハブ建材である ALC が，住宅用建材としてより広く使用されていく可 能性は大きい。このために, 後で述べる新製品, 新工法 の開発等により,この需要に応ずるための作業が続けら れている。

\section{2 新製品・新工法の開発の方向}

ALC の新製品と新工法の開発は,

（i） ALC の持つ欠点一一吸水性が大きい, 強度が 小さい，等をカバーする。

（ii）ALC をより高度の製品に改良し, 新需要に応 ずる。

等を目的とし，各メーカーでそれぞれ色々な開発が行な われている。これらの事柄は, 各社独自で行なわれてお り，本稿の立場で詳細に書くことが困難である。した がって以下項目を列記し，参考として新製品の実施例を 紹介することにする。かなりかたよった紹介となること を扔ことわりしておきたい。

\section{（1）工場仕上 ALC パネル}

ALC を工場で仕上げたものである。これはヨーロッ パ諸国では，すでに実用化されているものであるが，後 で述べる犬型パネルに工場仕上をしたものが多い。また この一種として, 工場で防水性を有する下地塗りを施し た防水 ALC も一部生産されている。

\section{（2）変形パネル}

ALC は，大型モールドに鋳込んだものをピアノ線で 切断して製造するので板状のものが一般的であるが，建 物出隅部の外壁パネルとしてL型断面のものが作られて いる。

\section{（3）大型パネル}

ALC を大型化したいといら要求は，かなり以前から あり，ヨーロッパでも，次に述べるような種々の方法に よって製品が作られている。わが国でもすでに実用化さ れているものもある。この中にはプレキャストカーテン ウォールと同様に使用され，開口部，サッシ組込，工場 仕上等もなされて, プレキャストカーテンウォールより かなり安価汇提供されているものもある。

ALC パネルの大型化は次のような方法がある。

a. 現在より大型のモールドを使用し, 広幅のパネル を作る。これは，ヨーロッパで行なわれているが， わが国では，現有の製造設備の相当な部分を作り変 える必要があり，未だ行なわれていない。

b. 普通コンクリートのプレキャスト版と同様に， 1 枚ずつ大型型わくを使用し平打ちで作る。この方法 もヨーロッパの一部で行なわれており，わが国でも 試みられている。プレキャスト版の問題点と同様に 種々の大型型わくを要すること, ALC の気泡の状 態を均一にしにくいこと, オートクレーブ養生の能 


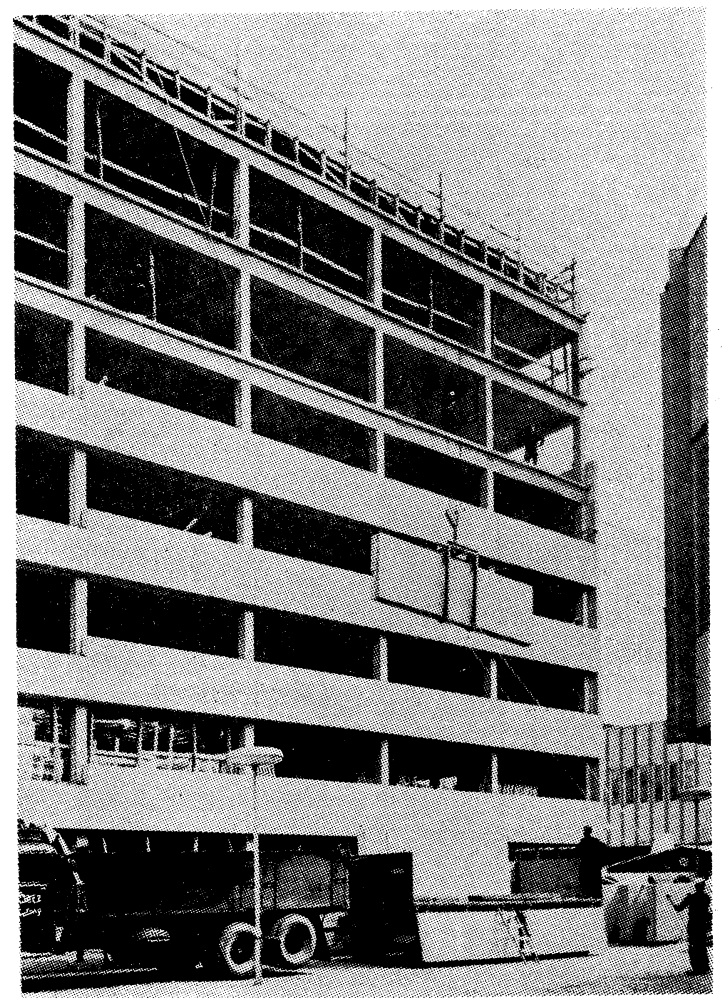

写真一3 ALC 大型パネル（大型モールド方式, ヨーロッパの実施例）

率が低くなりやすいこと等の問題がある。

c. 標準幅のパネルを集成する。これは，アングルフ レーム等に, 素材パネルをボルトで取り付ける方法 と, ポストテンション方式で素材パネルを 1 体化す る方法とがある。このうら特にポストテンション方 式が，素材間の目地が消せる，開口部を容易に取る ことができる等の利点により注目されている。これ らの方法による大型パネルは，ヨーロッパ，わが国 ともすで実用化されている。

\section{（4）耐力壁構造の改良}

ALC 耐力壁構造は,「ALC 構造設計基準」で認めら れており，ALCの低層住宅の工法として広く採用され ている。しかし，この構法は現場打ちの R C 臥梁を必要 とするので, この臥梁をプレキャストコンクリートや鉄 骨等の乾式工法に置きかえる試みが，ALC 協会あるい は各メーカーで，何回か作業された。特に，ALC 協会 で行なわれたプレキャスト臥梁の検討作業により，昭和 47 年 10 月, 建設省通達によって, プレキャスト臥梁も rALC 構造設計基準」の鉄筋コンクリート卧梁として 取扱われるようになった。乾式化といっても現実的な妥 協策としてジョイント部に湿式部分を残しており，末だ 完成された工法とはいいがたいが，連続施工による工期

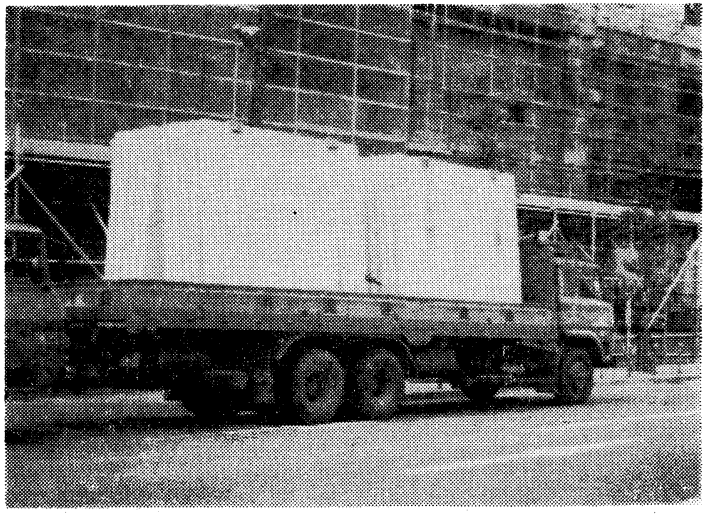

写真一4 ALC 大型パネルの輸送

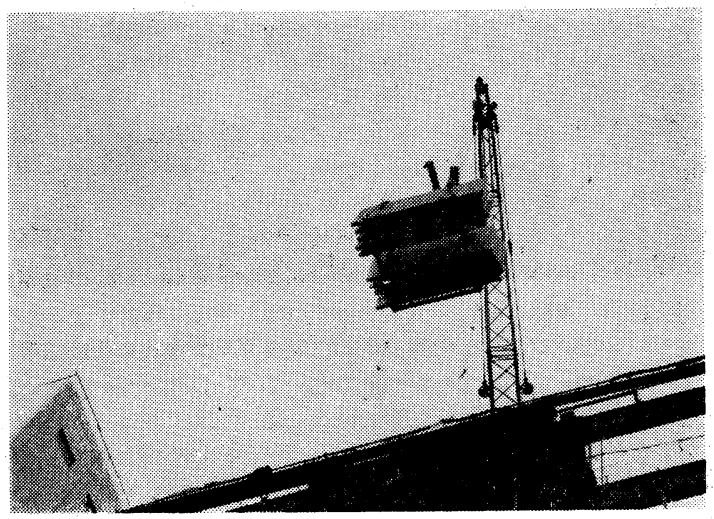

写真一5 ALC 大型パネルの荷上げ

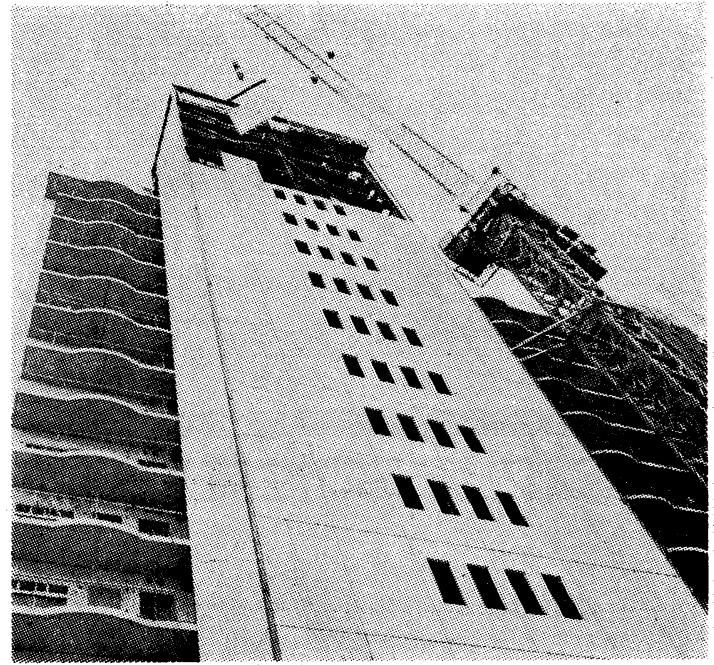

写真一6 ALC 大型パネルカーテンウォール（ポスト テンション方式) の実施例 (1) 某マンション 新築工事 (昭和 48 年 12 月) 


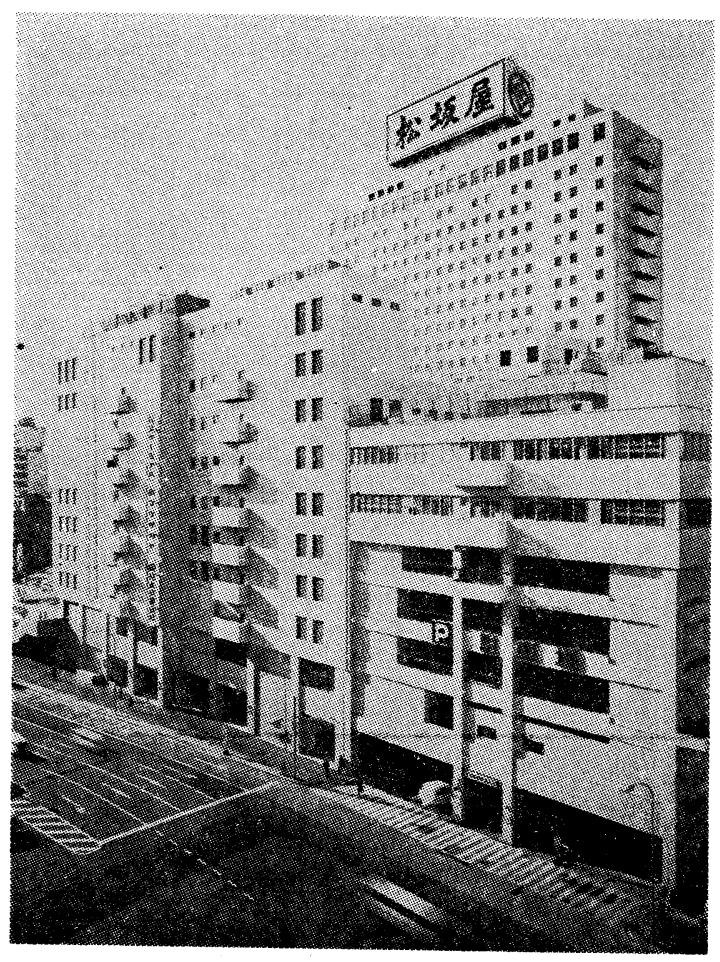

写真一1 ALC 大型パネルカーテンゥォール（ポストテンシ ョン方式) の実施例 (2) 某ターミナルビル新築工事

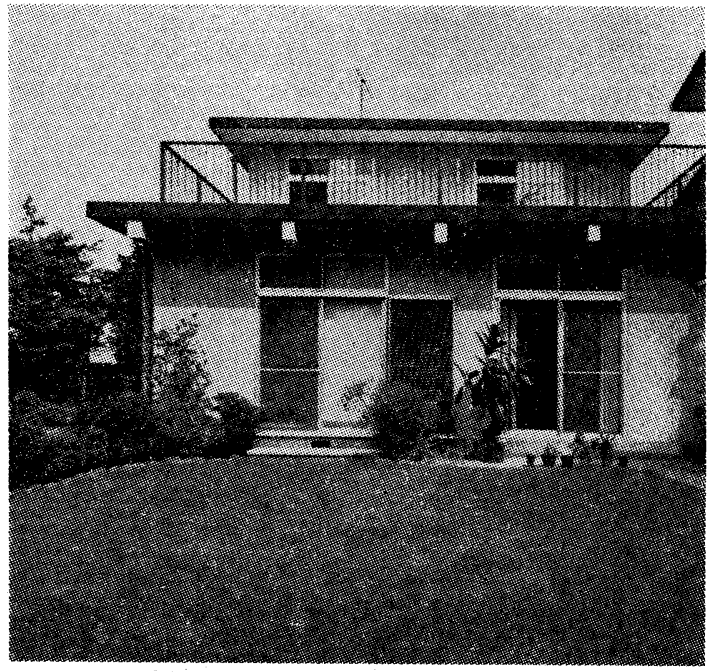

写真-8 ALC パネル耐力壁造住宅例

短縮が问能となったことや現場工事部分が減少したこと など，湿式工法の欠点はかなり改善されたといえよう。

これらの検討は，な抢今後続けられていくが, 新しい 乾式工法の実現が強く望まれている。

$$
\left(\begin{array}{c}
\text { 文责 }: \text { 杉田正路 } \\
\text { ALC 協会技術委員長 } \\
\text { シポレックス株式会社技術部長代理 }
\end{array}\right)
$$

